\title{
WSPÓŁPRACA MIĘDZYNARODOWA POLSKICH REGIONÓW W ZAKRESIE OCHRONY ZDROWIA
}

Współczesny świat cechują niezwykle zróżnicowane warunki życia jego mieszkańców. Nadal stosunkowo wiele jest miejsc, gdzie głód, brak wody, choroby, czy wojna (na ogół traktowane jako bieżący kryzys) tworzą codzienność. W takich warunkach ,polityka społeczna jako działalność nabiera charakteru globalnego i rozkłada się na wiele zadań, realizowanych przez wyspecjalizowane organizacje krajowe i międzynarodowe. Jak zwykle w polityce społecznej realizowane są równolegle różne cele: asekuruje się od ryzyka socjalnego, wyrównuje się szanse życiowe, zabezpiecza się szanse życiowe, zabezpiecza się prawa socjalne, zaspokaja istotne potrzeby, przekształca strukturę społeczną w taką, która będzie bardziej odporna na kryzys i niespodziewane wydarzenia". ${ }^{219}$ Pionierem badań nad ochroną zdrowia człowieka był Peter Townsend, który w swoich pracach stale przypominał o prawach człowieka, stawiając je przed gospodarką. Jego dzieła na temat problemu ubóstwa dotąd są przywoływane w naukowych opracowaniach tej problematyki. ${ }^{220}$

\section{Ochrona zdrowia jako kluczowy segment polityki społecznej}

Zdrowie jest uznawane przez ludzi za najcenniejszą wartość221 i najistotniejszy warunek istnienia ludzkości. Nic dziwnego, że największe obawy związane są z jego ewentualną utratą. Już u zarania swej działalności WHO (World Health Organisation) uznała, że zdrowie jest stanem zupełnej pomyślności fizycznej, psychicznej i społecznej, a nie jedynie brakiem choroby lub ułomności. ${ }^{222}$ Przyjmuje się również,

\footnotetext{
* $\quad$ Asystent w Katedrze Polityki Społecznej Wydziału Pedagogiki i Psychologii UwB.

** Zastępca Dyrektora Przedszkola z oddziałami integracyjnymi im. Jana Pawła II w Supraślu.

219 J. Auleytner, Polityka społeczna w Polsce i w świecie, Warszawa 2011, s. 139.

220 P. Townsend, The Koncept of Poverty, London 1970; P. Townsend, D. Gordon (ed.), World Poverty: New Policies to Defeat on Old Enemy, Bristol 2002, cyt. za: J. Auleytner, Polityka społeczna... op. cit., s. 141.

221 Por.: Diagnoza społeczna 2003. Warunki życia i jakości życia Polaków, pod red. J. Czapińskiego, T. Panka, Warszawa 2003.

222 Za: P. Krasucki, Optymalizacja systemu ochrony zdrowia. Koszty i korzyści, Warszawa 2005, s. 9.
} 
że „systemy zdrowotne obejmują (...) wszystkie organizacje, instytucje i zasoby, które są przeznaczone na działania zdrowotne". ${ }^{223} \mathrm{~W}$ związku z tym nadrzędnym celem systemowej ochrony zdrowia jest bezpieczeństwo zdrowotne państwa skorelowane z oczekiwaniami, co do stanu zdrowia społeczeństwa. Wskazuje się, że ochrona zdrowia powinna w idealnym ujęciu być: kompletna (właściwie przygotowana do pełnienia swojej misji), powszechna (obejmująca jak największą liczbę obywateli), dostępna (rozbudowana stosownie do liczby i rozmieszczenia obywateli), dostosowana kosztowo (w stosunku do kosztów utrzymania gospodarstw domowych), zorganizowana i wyposażona adekwatnie do potrzeb ludności. ${ }^{224}$

Dlatego do głównych celów polityki ochrony zdrowia należą: wydłużenie życia i eliminowanie przedwczesnych zgonów, profilaktyka i wczesne wykrywanie chorób, wzmacnianie odporności na choroby, minimalizowanie dyskomfortu i niesprawności, wzmacnianie potencjału zdrowotnego i odpowiednio profesjonalnej opieki medycznej dla wszystkich potrzebujących. ${ }^{225}$

W polityce społecznej bierze się pod uwagę czynniki ekonomiczne i społeczne wpływające na stan zdrowia jednostek, np.: miejsce zamieszkania, stan ochrony środowiska, warunki mieszkaniowe, poziom i styl życia, sposób odżywiania, higiena osobista, miejsce pracy, infrastruktura ochrony zdrowia, a także czynniki genetyczne. To wyjaśnia, dlaczego realizacja polityki ochrony zdrowia uwarunkowana jest wieloma wymiarami: politycznym (optyka widzenia problemów sfery ochrony zdrowia oraz sposobów ich rozwiązywania przez poszczególne ugrupowania polityczne), ekonomicznym (stan gospodarki i poziom życia obywateli) i demograficznym (struktura ludności oraz trendy jej rozwoju). ${ }^{226}$

W państwach wysoko rozwiniętych ochrona zdrowia ma status dobra publicznego. Konsekwencją tego stało się przyjęcie zasady solidaryzmu i współodpowiedzialności wszystkich za finansowanie wydatków na zdrowie tak, aby dosłownie wszyscy mogli skorzystać z pomocy medycznej. Ochrona zdrowia jest jednym z podstawowych zadań współczesnych państw, a zagadnienia jej dotyczące są przedmiotem zainteresowania różnych dyscyplin naukowych. Podstawowe zasady, na jakich opiera się polityka zdrowotna państw europejskich, to efektywność i solidaryzm. Efektywność w realizacji celów zdrowotnych polega na uzyskaniu jak najbardziej satysfakcjonującego efektu zdrowotnego, bez nadmiernego wzrostu wydatków w systemie i dotyczy kryteriów medycznych i ekonomicznych. Solidaryzm to współuczestniczenie w systemie różnych jednostek polegające na partycypacji w kosztach systemu (na rzecz zapewnienia - często zwiększonych - potrzeb lu-

223 Za: C. Włodarczyk, Reformy zdrowotne. Uniwersalny kłopot, Kraków 2003, s. 12.

224 Por.: A. Frączkiewicz-Wronka, Polityka ochrony zdrowia, [w:] Polityka społeczna. Wybrane zagadnienia, pod red. L. Frąckiewicz, Katowice 1994.

225 C. Włodarczyk, S. Paździoch, Systemy zdrowotne. Zarys problematyki, Kraków 2001, s. 33.

226 T. Szumilewicz, System zabezpieczenia społecznego w zarządzaniu zdrowiem, [w:] Zdrowie i jego ochrona. Między teorią a praktyką, pod red. V. Korporowicz, Warszawa 2004, s. 59. 
dzi uboższych, starszych, przewlekle chorych - w finansowaniu uczestniczy reszta społeczeństwa).

W krajach o wysokim dochodzie narodowym gros środków przeznaczonych na ochronę zdrowia pochodzi ze źródeł publicznych. Wydatki na zdrowie w grupie państw OECD wahają się w granicach 6-15\% PKB. Najwięcej w świecie na ochronę zdrowia przeznaczają Stany Zjednoczone (ponad 15\% PKB), a wśród państw europejskich do rekordzistów należą Austria, Belgia, Francja, Niemcy i Szwajcaria (ponad $10 \%$ PKB). Na tym tle skromnie przedstawia się sytuacja Polski, gdzie przeznacza się na ten cel tylko nieco ponad $6 \%$ PKB. ${ }^{227}$

Polskie doświadczenia drugiej połowy XX w., które ukształtowały sferę polityki społeczno-gospodarczej, w tym zdrowotnej, spowodowały jednocześnie opóźnienia cywilizacyjne Polski w stosunku do innych aktualnych członków Unii Europejskiej. Dobrą stroną takiego obrotu sprawy jest możliwość korzystania z dorobku i doświadczeń innych państw. W latach 80 . i na początku transformacji pojawiły się różne koncepcje reformowania sektora ochrony zdrowia oscylujące wokół rozwiązań ubezpieczeniowych lub państwowej służby zdrowia. Przyjęte od 1 stycznia 1999 r. rozwiązania w polskiej ochronie zdrowia miały być zgodne z treścią art. 68 Konstytucji RP nakładającego na władze publiczne obowiązek zapewnienia obywatelom, niezależnie od ich sytuacji materialnej, równego dostępu do świadczeń opieki zdrowotnej finansowanej ze środków publicznych. ${ }^{228}$

Generalnie reforma systemu ochrony zdrowia oparta została na zasadzie rozdziału płatnika i wykonawcy świadczeń, gdzie rolę tego pierwszego objęły kasy chorych (16 województw i jedna branżowa m.in. dla żołnierzy zawodowych, policjantów i ich rodzin). Płatnikiem odpowiedzialnym za świadczenia wysokospecjalistyczne pozostał budżet państwa, natomiast wykonawcami świadczeń zostały podmioty, które zawarły kontrakt z kasą chorych, tzw. świadczeniodawcy. Właścicielami mienia większości świadczeniodawców zostały samorządy terytorialne lub organy centralnej administracji rządowej (szpitale specjalistyczne). Ostatecznie kasy chorych zostały zastąpione przez Narodowy Fundusz Zdrowia (NFZ) - jeden z największych funduszy celowych i składkowych, który ma wspomagać politykę społeczną państwa. W strukturze centrali Funduszu działają:

- Departament Świadczeń Opieki Zdrowotnej,

- Departament Gospodarki Lekami,

- Departament Spraw Świadczeniobiorców,

227 M. Kubiak, Polityka ochrony zdrowia, [w:] Wprowadzenie do polityki społecznej, pod red. R. Gabryszak, D. Magierka, Warszawa 2009, s. 144.

228 Art. 68 Konstytucji RP stanowi, że władze publiczne, zapewniając równy dostęp do świadczeń opieki zdrowotnej - obowiązane są do zapewnienia szczególnej opieki zdrowotnej dzieciom, kobietom, osobom niepełnosprawnym i osobom w podeszłym wieku. Por.: U. Drozdowska, S. Sikorski, Kształtowanie się systemu opieki zdrowotnej w Polsce po przemianach ustrojowych 1989 r., [w:] Uwarunkowania systemu opieki zdrowotnej w Polsce, pod. red. T. Mróz, Białystok 2012, s. 63 i n. 
- Departament do Spraw Służb Mundurowych. ${ }^{229}$

Budżet Narodowego Funduszu Zdrowia z roku na rok rośnie. O ile w 2004 roku przychody wynosiły $31743,6 \mathrm{mln}$ zł, to w 2007 roku już $43425,8 \mathrm{mln}$ zł. ${ }^{230} \mathrm{Z}$ kolei w roku 2012 całkowity budżet na refundację wynosił aż $10445819 \mathrm{mln}$ zł. ${ }^{231}$ Popyt na usługi zdrowotne rośnie bardzo szybko wskutek rozwoju świadomości i kultury zdrowotnej, oferty nowych i obiecujących technologii medycznych oraz starzenia się społeczeństw. Wymogiem współczesności staje się zatem podniesienie skuteczności medycznej, jak i efektywności kosztowej systemów ochrony zdrowia. ${ }^{232}$

Bezpośrednią opiekę nad swoimi pacjentami objął tzw. lekarz pierwszego kontaktu, pełniąc rolę pośrednika między specjalistą a pacjentem. Reforma miała opierać się na zasadach solidarności społecznej, samorządności, prawie wyboru lekarza, a także zapewnieniu równego dostępu do opieki medycznej. ${ }^{233}$ Jej oceny są kontrowersyjne, a na obiektywny komentarz opinia publiczna będzie zapewne zmuszona poczekać. Wszak kraje tzw. „starej Unii Europejskiej” kształtując swe polityki zdrowotne od półwiecza - w warunkach europejskiej integracji gospodarczej, wolnego rynku i demokracji ustrojowej - nadal borykają się z rozmaitymi trudnościami. ${ }^{234}$ Nie zmienia to faktu, że $\mathrm{z}$ ich doświadczeń można i należy korzystać. W tym celu zaś należy współpracować, także na szczeblu regionalnym.

\section{Kompetencja polskiego województwa wobec ochrony zdrowia}

Złożoność ochrony zdrowia w zestawieniu ze wzrostem znaczenia polskich województw pozwala przyjąć tezę, że polskie województwa mogą, powinny, a co najważniejsze, wydaje się, że chcą podejmować działania w zakresie ochrony zdrowia.

Początkowo należy odpowiedzieć na podstawowe pytania: czym jest województwo? i jaka jest jego rola w państwie? Teoretycznie - województwo jest ogniwem administracji państwowej i samorządowej, a jednocześnie społecznością konkretnych, związanych z nim ludzi. Art. 1. Ustawy o samorządzie województwa stanowi, że: „Mieszkańcy województwa tworzą z mocy prawa regionalną wspólnotę samorządową". ${ }^{235}$ Przepis art. 14. przywołanej ustawy szczegółowo określa zadania województw:

„1. Samorząd województwa wykonuje zadania o charakterze wojewódzkim określone ustawami, w szczególności w zakresie: 1) edukacji publicznej, w tym

J. Auleytner, Polityka społeczna..., op. cit., s. 327.

Ibidem, s. 328.

Komunikat NFZ, oficjalna strona internetowa Narodowego Funduszu Zdrowia, tryb dostępu: http://www.nfz.gov. $\mathrm{pl} /$ new/index.php?katnr=0\&dzialnr=2\&artnr=5074\&szukana=bud\%BFet\%2B2012, na dzień 14.12.2012 r.

M. Kubiak, Polityka ochrony zdrowia..., op. cit., s. 161.

Ibidem, s. 155.

J. Auleytner, Polityka społeczna..., op. cit., s. 208.

Ustawa o samorządzie województwa z dnia 5 czerwca 1998 r., Dz.U. z 1998 r. Nr 91, poz. 576, s. 1. 
szkolnictwa wyższego; 2) promocji i ochrony zdrowia; 3) kultury oraz ochrony zabytków i opieki nad zabytkami; 4) pomocy społecznej; 5) polityki prorodzinnej; 6) modernizacji terenów wiejskich; 7) zagospodarowania przestrzennego; 8) ochrony środowiska; 9) gospodarki wodnej, w tym ochrony przeciwpowodziowej, a w szczególności wyposażenia i utrzymania wojewódzkich magazynów przeciwpowodziowych; 10) transportu zbiorowego i dróg publicznych; 11) kultury fizycznej i turystyki; 12) ochrony praw konsumentów; 13) obronności; 14) bezpieczeństwa publicznego; 15) przeciwdziałania bezrobociu i aktywizacji lokalnego rynku pracy; 15a) działalności w zakresie telekomunikacji; 16) ochrony roszczeń pracowniczych w razie niewypłacalności pracodawcy." ${ }^{236}$

Z powyższego wynika, że połowę zadań nałożonych ustawowo na polskie województwo stanowi szeroko pojęta polityka społeczna. Wedle Witolda Turnowieckiego i Michała Polaka ta ostatnia obejmuje bowiem (m.in.):

- politykę rodzinną,

- politykę zatrudnienia, płac, warunków i ochrony pracy,

- politykę ochrony zdrowia,

- politykę oświatową,

- politykę kształtowania kultury,

- politykę zabezpieczenia społecznego i opieki społecznej,

- politykę ochrony środowiska naturalnego,

- politykę prewencji, zwalczania zjawisk patologii społecznej. ${ }^{237}$

Do refleksji skłania przejście z poziomu krajowego (ustawowego) na poziom województwa (dokumenty strategiczne). Na przykład w województwie podlaskim Wojewódzka Strategia Polityki Społecznej na lata 2010-2018 (dokument przygotowany przez Regionalny Ośrodek Polityki Społecznej w Białymstoku) w rozdziale trzecim (3.2 System opieki zdrowotnej, w tym profilaktyka i rozwiazywanie problemów uzależnień) nie ma odniesienia wprost do współpracy międzynarodowej w tym zakresie. Podejmowane działania mają (należy mieć nadzieję, że „póki co”) charakter przede wszystkim działalności wizerunkowej. ${ }^{238}$ Perspektywy konkretyzacji dla działań o wymiarze międzynarodowym rysują się w przygotowanej przez zespół ekspertów Regionalnego Ośrodka Polityki Społecznej analizie SWOT ochrony zdrowia w województwie podlaskim.

236 Ibidem, s. 5. Por. U. Drozdowska, S. Sikorski, Kształtowanie się systemu..., op. cit., s. 123 i n.

237 W. Turnowiecki, Polityka społeczna, Gdańsk 2004, s. 10; M. Polak, Pojęcie, zakres i geneza polityki społecznej, [w:] Wprowadzenie do polityki społecznej, pod red. R. Gabryszak i D. Magierka, Warszawa 2009, s. 22-23. Na ten temat także: A. Frączkiewicz-Wronka, Samorządowa polityka ochrony zdrowia, [w:] Samorządowa polityka społeczna, pod red. tejże, Warszawa 2003.

238 Wojewódzka Strategia Polityki Społecznej na lata 2010-2018, Regionalny Ośrodek Polityki Społecznej w Białymstoku, Białystok 2010, s. 41-45. 


\section{Tabela 1. Analiza SWOT obszaru zdrowia przygotowana przez Zespół Regionalnego Ośrodka Polityki Społecznej w Białymstoku.}

\begin{tabular}{|c|c|}
\hline MOCNE STRONY & SŁABE STRONY \\
\hline $\begin{array}{l}\cdot \text { wykształcona kadra } \\
\cdot \text { położenie przygraniczne } \\
\cdot \text { wysokie zaufanie do publicznych } \\
\text { zakładów opieki zdrowotnej } \\
\cdot \text { równomierne rozmieszczenie ZOZ-ów } \\
\cdot \text { zrestrukturyzowane w dużym stopniu } \\
\text { zakłady opieki zdrowotnej drugiego } \\
\text { poziomu referencyjnego } \\
\cdot \text { funkcjonujące placówki naukowo- } \\
\text { badawcze } \\
\cdot \text { Uniwersytet Medyczny w Białymstoku } \\
\text { i inne uczelnie kształcące w zawodach } \\
\text { medycznych } \\
\cdot \text { umacnianie się dużych aglomeracji } \\
\text { miejskich } \\
\cdot \text { położenie geograficzne - czyste } \\
\text { środowisko } \\
\cdot \text { duże zainteresowanie personelu } \\
\text { medycznego doskonaleniem } \\
\text { zawodowym i podwyższaniem } \\
\text { kwalifikacji } \\
\cdot \text { potencjał do realizacji programów } \\
\text { profilaktycznych }\end{array}$ & 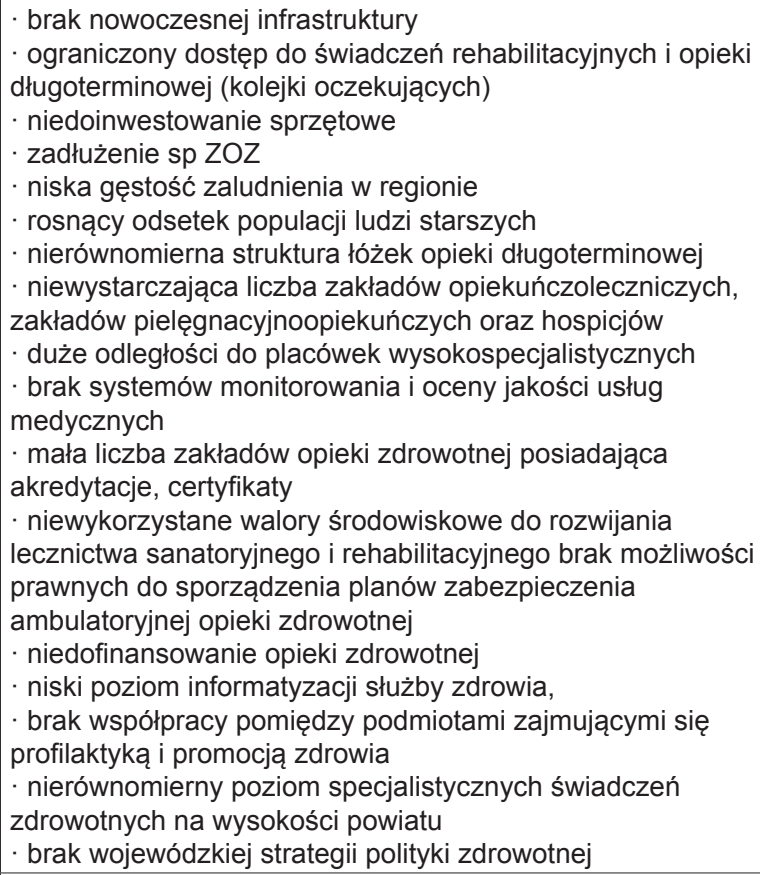 \\
\hline SZANSE & ZAGROŻENIA \\
\hline \begin{tabular}{|l}
$\cdot$ przystąpienie do Unii Europejskiej \\
$\cdot$ wzrost jakości udzielanych świadczeń \\
zdrowotnych \\
$\cdot$ wzrost konkurencyjności \\
$\cdot$ wzrost dostępności do \\
wysokospecjalistycznych świadczeń \\
zdrowotnych \\
$\cdot$ społeczne przyzwolenie \\
na konieczność unowocześnienia \\
publicznych ZOZ \\
$\cdot$ brak rejonizacji \\
$\cdot$ potencjał do tworzenia oferty \\
turystycznej dla osób starszych, \\
alternatywnej do sanatoryjno- \\
rehabilitacyjnej (ukształtowanie terenu \\
szlaki turystyczne, mikroklimat) \\
$\cdot$ możliwość kształcenia kadry \\
$\cdot$ informatyzacja \\
$\cdot$ dodatkowe ubezpieczenia
\end{tabular} & $\begin{array}{l}\text { - emigracja wykształconej kadry medycznej (lekarzy } \\
\text { i pielęgniarek) } \\
\text { - brak koordynacji w realizacji programów profilaktycznych } \\
\text { i innych działań z zakresu promocji zdrowia } \\
\text { - niskie nakłady budżetów lokalnych na promocje zdrowia } \\
\text { - niedofinansowanie opieki zdrowotnej } \\
\text { - niedostateczne zaopatrzenie w nowoczesny sprzęt } \\
\text { medyczny i rehabilitacyjny w placówkach ochrony zdrowia } \\
\text { - niewystarczająca opieka medyczna w szkołach } \\
\text { - rozwijanie medycyny naprawczej a niedocenianie działań } \\
\text { profilaktycznych } \\
\text { - niestabilny system finansowania świadczeń }\end{array}$ \\
\hline
\end{tabular}

Źródto: Wojewódzka Strategia Polityki Spotecznej na lata 2010-2018, Regionalny Ośrodek Polityki Spolecznej w Biatymstoku, Biatystok 2010, s. 45. 
Współpraca międzynarodowa...

Już pobieżna analiza kompetencji i wybranej dokumentacji potwierdza tezę, że polskie województwa zajmują się ochroną zdrowia. Powstaje kolejne pytanie - czy wobec międzynarodowego charakteru tej problematyki województwa współpracują międzynarodowo?

\section{Uwarunkowania formalne aktywności polskiego województwa w stosunkach międzynarodowych}

Kluczowym aktem prawa polskiego jest Konstytucja Rzeczpospolitej Polskiej z 1997 r. ${ }^{239}$ Jej artykuł 172 stanowi, że: ,jednostka samorządu terytorialnego ma prawo przystępowania do międzynarodowych zrzeszeń społeczności lokalnych i regionalnych oraz współpracy ze społecznościami lokalnymi i regionalnymi innych państw”, wskazując jednocześnie, że zasady takiej działalności powinny zostać określone ustawowo. ${ }^{240}$ Systemowo, należy wskazać też artykuł 168 Traktatu o funkcjonowaniu Unii Europejskiej, a zwłaszcza pierwszy akapit jego ustępu drugiego: Unia zachęca do współpracy między Państwami Członkowskimi w dziedzinach określonych $w$ niniejszym artykule oraz, jeśli to konieczne, wspiera ich działania. Unia zachęca w szczególności do współpracy między Państwami Członkowskimi w celu zwiększenia komplementarności ich ustug zdrowotnych $w$ regionach przygranicz$n y c h .{ }^{241}$ Prawo unijne zatem nie tylko nie ogranicza współpracy zagranicznej regionów (w tym - polskich województw) w zakresie ochrony zdrowia, ale wręcz do niej zachęca.

W przypadku województw samorządowych zasady przystępowania do międzynarodowych zrzeszeń określone są w ustawie z dnia 5 czerwca 1998 r. o samorządzie wojewódzkim. ${ }^{242}$ Ujęto je w rozdziale 6 ustawy zatytułowanym „Współpraca zagraniczna". Tytułowa współpraca zagraniczna województwa prowadzona jest na podstawie uchwalonych przez sejmik województwa ,,priorytetów współpracy zagranicznej województwa”. Dokument ten, przyjęty bezwzględną większością głosów ustawowego składu sejmiku województwa, za zgodą ministra właściwego do spraw zagranicznych, określa:

- główne cele współpracy zagranicznej,

- priorytety geograficzne przyszłej współpracy,

- zamierzenia co do przystępowania do międzynarodowych zrzeszeń regionalnych.

239 Konstytucja Rzeczypospolitej Polskiej z dnia 2 kwietnia 1997 r., Dz.U. Nr 78, poz. 483.

240 M. Kołodziejski, K. Szmigiel, Międzynarodowa współpraca transgraniczna i międzyregionalna w kontekście polityki regionalnej państwa na lata 2007-2013, ekspertyza wykonana na zlecenie Departamentu Polityki Regionalnej w MGiP, Warszawa 2004, s. 6 i n.

241 Dz.U. UE. C 326 z 26 października 2012 r., s. 123.

242 Dz.U. Nr 91, poz. 576. 
Ustawa zastrzega, że współpraca województwa ze społecznościami regionalnymi innych państw prowadzona jest zgodnie z prawem wewnętrznym, polityką zagraniczną państwa i jego międzynarodowymi zobowiązaniami, w granicach zadań i kompetencji województwa. Innymi słowy, priorytety współpracy zagranicznej województwa, projekty umów o współpracy zagranicznej oraz umowy o przystąpieniu do międzynarodowych zrzeszeń regionalnych muszą zostać zaakceptowane przez ministra spraw zagranicznych. Ta ostatnia kwestia została szczegółowo uregulowana przez ustawę z 15 września 2000 roku o zasadach przystępowania jednostek samorządu terytorialnego do międzynarodowych zrzeszeń społeczności lokalnych i regionalnych, która weszła w życie 29 stycznia 2001 r. ${ }^{243}$

W poszukiwaniu odpowiedzi na pytanie: na ile polskie województwa angażują się we współpracę międzynarodową w zakresie szeroko pojętej polityki społecznej (w tym realizacji profilaktyki uzależnień)? nieodzowna wydaje się analiza przykładowych ,priorytetów współpracy międzynarodowej województwa”. Stosowny dokument dla województwa podlaskiego nie posiada jednak odniesień wprost do wskazanej problematyki. Z drugiej strony województwa dysponują zaskakująco szerokim wachlarzem możliwości wspierania/realizacji swoich zadań w oparciu o elementy współpracy międzynarodowej. Do najistotniejszych zaliczyć należy udział $\mathrm{w}$ zrzeszeniach międzynarodowych, reprezentowanie województw w organizacjach międzynarodowych (zwłaszcza: Komitet Regionów Unii Europejskiej oraz Kongres Władz Lokalnych i Regionalnych Rady Europy) i posiadanie własnych przedstawicielstw zagranicznych (głównie w Brukseli). Dla przykładu w ,priorytetach współpracy międzynarodowej województwa (podlaskiego)" opisano (...) wykorzystanie Regionalnego Biura Województwa Podlaskiego w Brukseli w zakresie:

1. Reprezentowania interesów Województwa Podlaskiego i kształtowania pozytywnego wizerunku regionu na forum instytucji europejskich (m.in. poprzez działania informacyjne i promocyjne oraz kontakty z przedstawicielami biur innych europejskich regionów w Brukseli);

2. Promocji Województwa Podlaskiego;

3. Gromadzenia i weryfikacji bieżących informacji uzyskanych w instytucjach Unii Europejskiej ważnych z punktu widzenia interesów gospodarczych województwa;

4. Pośrednictwa w zdobywaniu partnerów dla współpracy międzyregionalnej;

5. Pomocy w pozyskiwaniu środków z funduszy strukturalnych, współpracy z instytucjami UE $\mathrm{w}$ zakresie wspierania realizacji programów i projektów służących rozwojowi województwa; 
6. Informowania administracji regionalnej o zmianach prawnych, procedurach i decyzjach zapadających w organach Unii Europejskiej. ${ }^{244}$

Ponad połowa zadań przedstawicielstwa może być z powodzeniem wykorzystana do działań służących współpracy w zakresie szeroko pojętej ochrony zdrowia. Wśród potencjalnych efektów pracy przedstawicielstwa szczególnie istotne wydają się projekty międzynarodowe (najczęściej finansowane z funduszy UE, Europejskiego Obszaru Gospodarczego i środków norweskich), które mogą zapewnić województwom nie tylko transfer pieniędzy, ale przede wszystkim pozyskanie innowacyjnej metodologii i doświadczeń praktycznych. Nie wdając się w pogłębione rozważania, można zauważyć, że możliwości działania polskich województw (w zakresie ochrony zdrowia) na forum międzynarodowym jest wiele. Zastanawia, jak to wygląda w praktyce?

\section{Międzynarodowa praktyka polskich województw w zakresie ochrony zdrowia}

Dla zbadania praktyki polskich województw w zakresie ochrony zdrowia zostały zrealizowane badania ankietowe, które swoim zasięgiem objęły urzędy marszałkowskie we wszystkich 16 polskich województwach. ${ }^{245}$ Pytania zawarte w rozesłanym kwestionariuszu ankiety zostały skierowane do osób (komórek) odpowiedzialnych za współpracę zagraniczną.

Samorządy województw poproszono o scharakteryzowanie prowadzonej przez nie polityki zagranicznej. Dokładniej, ankietowani mieli odpowiedzieć „tak” lub „nie" dla przedsięwzięć/obszarów podstawowych realizowanych w obszarach grupy kontrolnej. Aktywność respondentów na arenie międzynarodowej jest szeroka, gdyż pozytywnej odpowiedzi udzieliły prawie wszystkie województwa. Wskazania negatywne były nieliczne.

244 Patrz: oficjalna strona internetowa Regionalnego Biura Województwa Podlaskiego w Brukseli, tryb dostępu: http://www.podlaskie.eu/biuro-w-brukseli

245 M. Perkowska, Opracowanie wyników badania empirycznego zespołu prof. M. Perkowskiego z Wydziału Prawa UwB w ramach BST „Prawo rozwoju regionalnego”, w odniesieniu do zagadnienia „Ochrona zdrowia i przeciwdziałanie patologiom społecznym”, w porozumieniu i za udostępnieniem. 
Marta Perkowska, Iwona Lewkowicz

\section{Wykres 1. Obszary działalności polskich województw}

o charakterze międzynarodowym

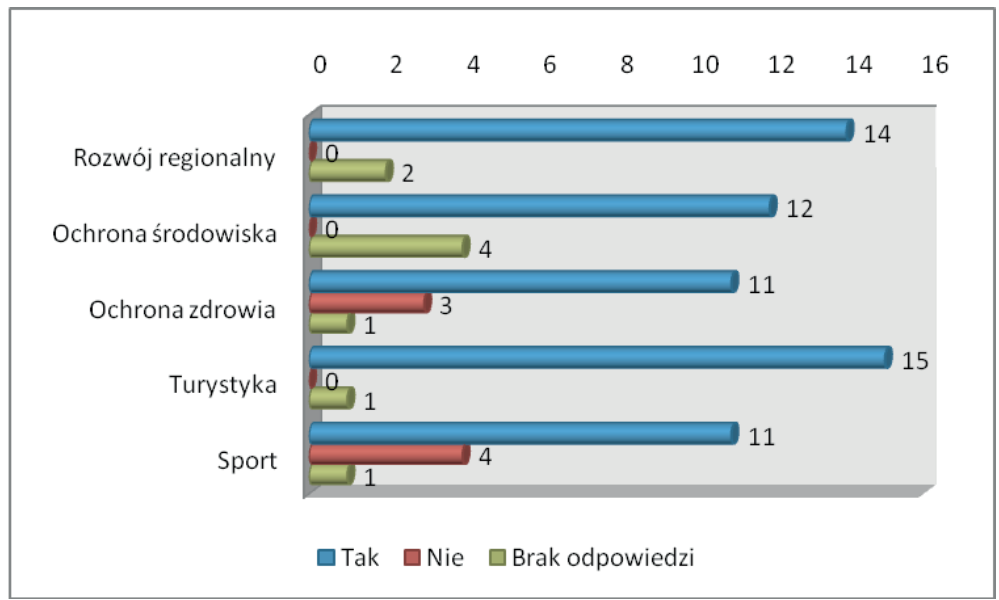

Źródto: Opracowanie własne $(N=16)$

Uzyskane wyniki napawają optymizmem, bo aż 11 spośród 16 województw prowadzi działania o charakterze międzynarodowym w obszarze ochrony zdrowia.

Wykres 2. Aktywność zagraniczna polskich województw w obszarze ochrony zdrowia

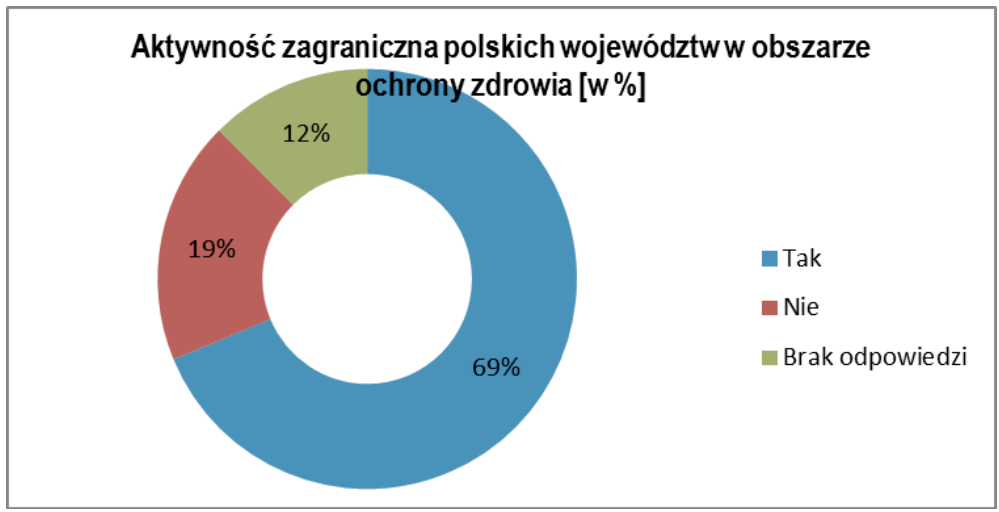

Źródto: Opracowanie własne $(N=16)$

Entuzjazm studzi z kolei analiza wyników uzyskanych w odpowiedzi na pytanie o przynależność polskich województw do międzynarodowych zrzeszeń regionów, województw i ich odpowiedników w obszarze ochrony zdrowia. 
Współpraca międzynarodowa...

Wykres 3. Przynależność polskich województw do międzynarodowych zrzeszeń regionów w obszarze ochrony zdrowia.

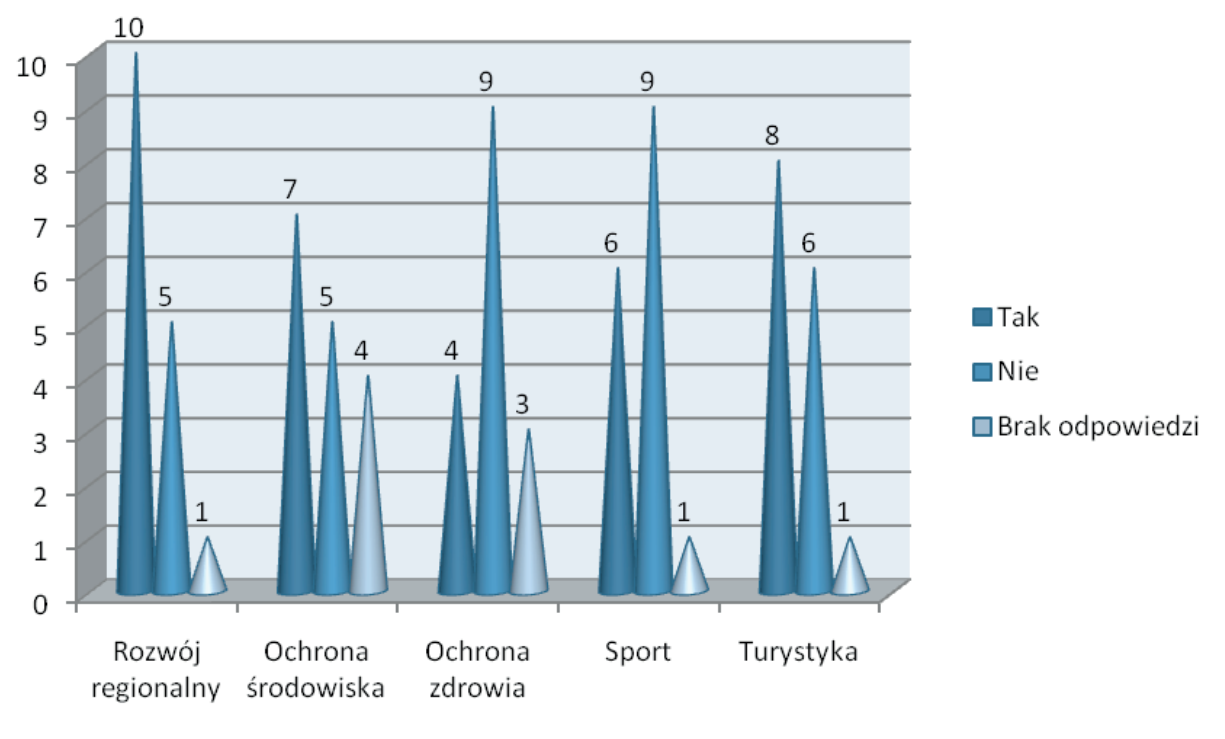

Źródło: Opracowanie własne $\quad(N=16)$

Jedynie cztery województwa udzieliły odpowiedzi twierdzącej.

Wykres 4. Udział w międzynarodowych zrzeszeniach regionów/województw i ich odpowiednikach w obszarze ochrony zdrowia

Aktywność polskich województw w międzynarodowych zrzeszeniach regionów/województw i ich odpowiednikach w obszarze grupy kontrolnej [w \% oraz liczbach bezwzględnych]

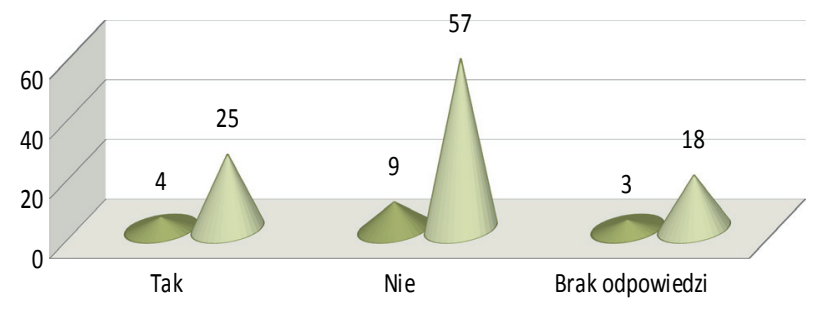

Źródto: Opracowanie własne $(N=16)$ 
Wykres 5. Przedstawiciele polskich województw a prace organów organizacji międzynarodowych w obszarze ochrony zdrowia

\section{Przedstawiciele polskich województw w pracach organów organizacji międzynarodowych w obszarze grupy kontrolnej [w \% oraz liczbach bezwzględnych]}

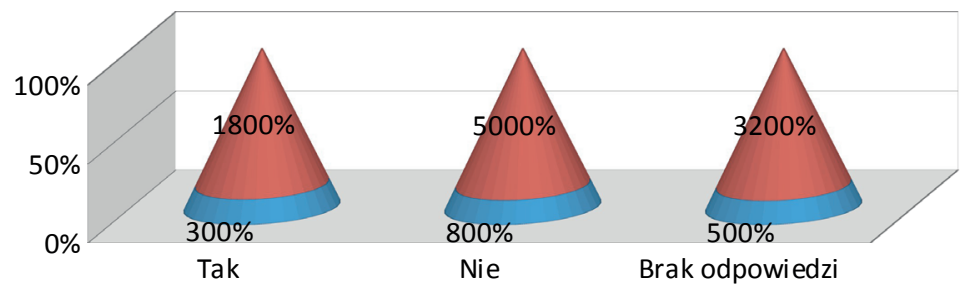

Źródło: Opracowanie własne (N=16)

Wskazywano zwłaszcza na przynależność/prace w ramach: ERB (Euroregion Bałtyk), BSSSC (Baltic Sea States Subregionals Cooperation), FPRPB (Forum Parlamentów Regionalnych Południowego Bałtyku), Komitet Regionów UE, AER (Zgromadzenie Regionów Europy), European Social Network. Na szczególną uwagę w tym miejscu zasługuje województwo podlaskie, które od 27 stycznia 2012 roku jest pełnoprawnym członkiem stowarzyszenia „Sieć Regionów Europejskich na Rzecz Ochrony Zdrowia” (w skrócie „EUREGHA”). Stowarzyszenie jest organizacją typu non-profit. Działa na podstawie przepisów prawa belgijskiego, tj. ustawy z dnia 27 czerwca 1921 o stowarzyszeniach typu non-profit, międzynarodowych stowarzyszeniach non-profit oraz fundacjach. Cele, jakie stawia przed sobą „EUREGHA”, przedstawia jej statut. W szczególności:

„Art. 3. Stowarzyszenie nie kieruje się osiagnięciem zysku, a jego celem jest ustanowienie wspótpracy pomiędzy europejskimi władzami regionalnymi $i$ lokalnymi, szczególnie ich organami zajmujacymi się opieka zdrowotna $i$ zdrowiem publicznym $w$ Europie, a także ustanowienie $w$ tym zakresie bliższej wspótpracy $z$ instytucjami Unii Europejskiej, a także innymi organizacjami międzynarodowymi i publicznymi zwiazanymi z opieka zdrowotna i zdrowiem publicznym na świecie.

Art. 4. - Stowarzyszenie wspiera działania i inicjatywy, mając na celu:

- tworzenie synergii pomiędzy regionami i podmiotami zajmujacymi się opieka zdrowotna, $w$ odniesieniu do organizacji niższego szczebla niż narodowe oraz krajowych organizacji zwiazanych z systemem shuzby zdrowia; zachowując jednocześnie polityczną neutralność; 
- prowadzenie platformy wspótpracy EUREGHA pomiędzy różnymi podmiotami działajacymi w dziedzinie opieki zdrowotnej;

- wzmocnienie kooperacji/wspótpracy pomiędzy regionalnymi i lokalnymi a europejskimi instytucjami działajacymi $w$ dziedzinie opieki zdrowotnej;

- promowanie cennego wktadu wnoszonego przez regionalne i lokalne wtadze oraz lokalne i regionalne władze zdrowotne do tworzenia europejskiej polityki ochrony zdrowia i kwestii z nia zwiazanych;

- promowanie wiedzy na temat funkcjonowania regionalnych i lokalnych systemów stużby zdrowia;

- propagowanie działań przyczyniajacych się do popularyzacji wiedzy na temat funkcjonowania regionalnych/lokalnych systemów slużby zdrowia na szczeblu europejskim". ${ }^{246}$

Budujące jest, że współpraca międzynarodowa polskich województw sygnowana jest na ogół oficjalnymi dokumentami. Szczegółowych informacji na ten temat dostarcza jedno z pytań zawartych w ankiecie, w którym to respondenci zostali poproszeni o udzielenie odpowiedzi: czy reprezentowane województwa są stronami umów międzynarodowych porozumień/innych udokumentowanych form współpracy międzynarodowej w zakresie przedmiotowym: ochrona zdrowia?

Wykres 6. Województwo jako strona umów, porozumień, innych form udokumentowanej współpracy w odniesieniu do ochrony zdrowia

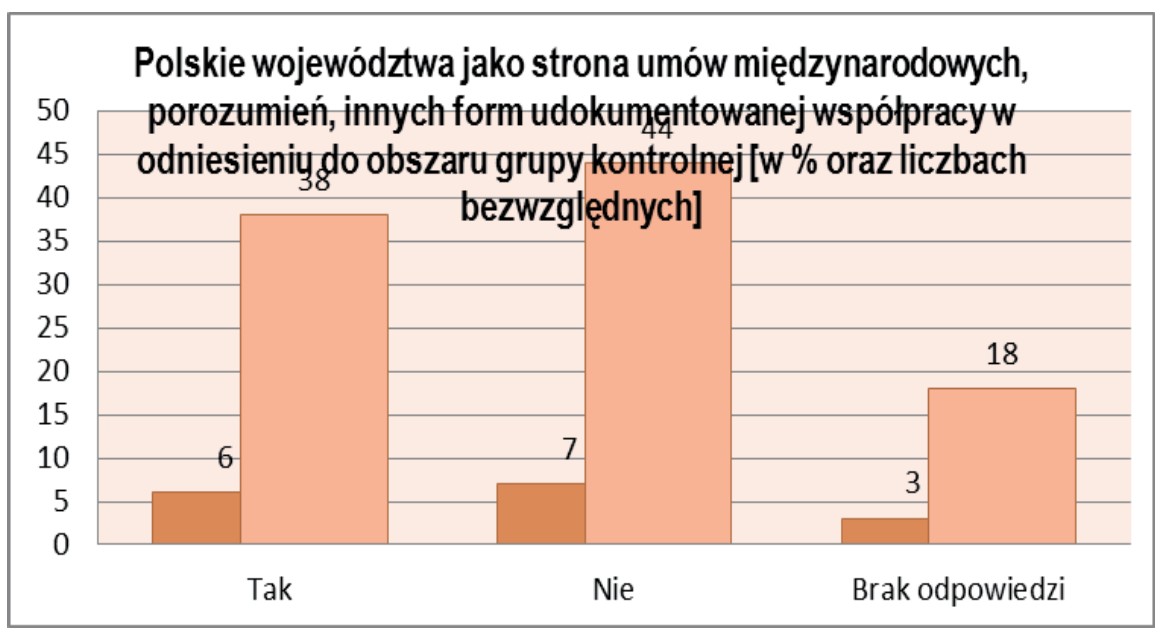

Źródto: Opracowanie własne ( $N=16)$

246 Zob. oficjalna strona internetowa stowarzyszenia „Sieć Regionów Europejskich na Rzecz Ochrony Zdrowia”, tryb dostępu: www.euregha.net., dnia 11.10.2012 r. 


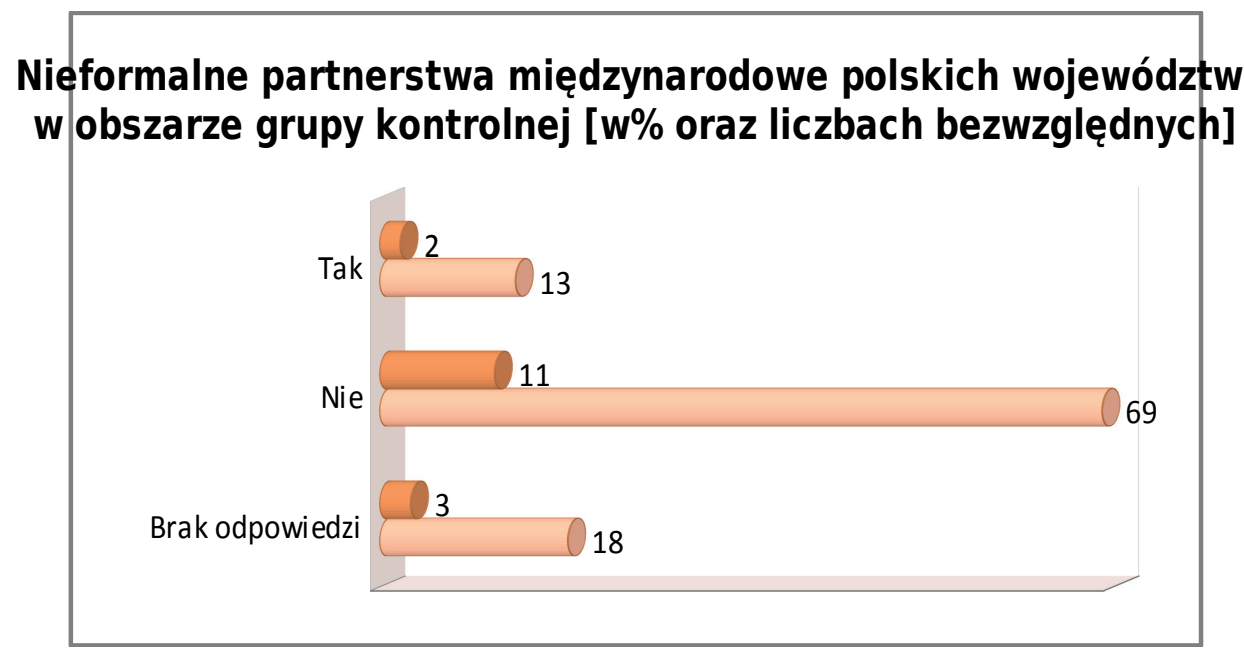

Źródło: Opracowanie własne $(N=16)$

W ramach obszaru ochrony zdrowia twierdzacych odpowiedzi udzieliło siedem województw: kujawsko-pomorskie, śląskie, warmińsko-mazurskie. Szczególnie interesująco prezentuje się działalność województw: Województwo Małopolskie - Porozumienie kooperacyjne zawarte pomiędzy Urzędem Marszałkowskim Województwa Małopolskiego, Szpitalem Specjalistycznym im. dr J. Babińskiego SPZOZ w Krakowie i Centrum Psychiatrii w Weissenau w ramach partnerstwa regionalnego pomiędzy Małopolską i Południową Wirtembergią. Województwo mazowieckie nie jest stroną umów międzynarodowych, ale wiele porozumień o współpracy międzyregionalnej, których jest stroną w zakresie przedmiotowym, zawiera ochronę zdrowia. Województwo podlaskie przystąpiło w 2012 r. do Stowarzyszenia EUREGHA. Województwo pomorskie w ramach międzynarodowych porozumień dwustronnych z regionami partnerskimi realizuje przedsięwzięcia/projekty, dotyczące również zdrowia, np. projekt „E-healthforregions”.

W obszarze ochrony zdrowia województwo opolskie zawarło następujące umowy o partnerstwie i współpracy: 1. Hans Prinzhorn Klinik w Hemer, 2. Szpital Psychiatryczny we Lwowie, Szpital Psychiatryczny w Iwano- Frankiwsku. Województwo śląskie ochronę zdrowia wpisało jako możliwą dziedzinę współpracy W porozumieniu o współpracy dwustronnej z Adżarią (Gruzja). W porozumieniu z Walią zaplanowało zaś wymianę doświadczeń związanych z przeciwdziałaniem wykluczeniu społecznemu, w porozumieniu z Dolnym Renem - wymianę doświadczeń związanych z polityką społeczną. 
Jedynie około $1 / 5$ polskich województw wskazało na udział swojego zagranicznego przedstawicielstwa w realizacji zadań w zakresie ochrony zdrowia (wykres 8).

Wykres 8. Przedstawicielstwo zagraniczne a realizacja zadań w zakresie ochrony zdrowia

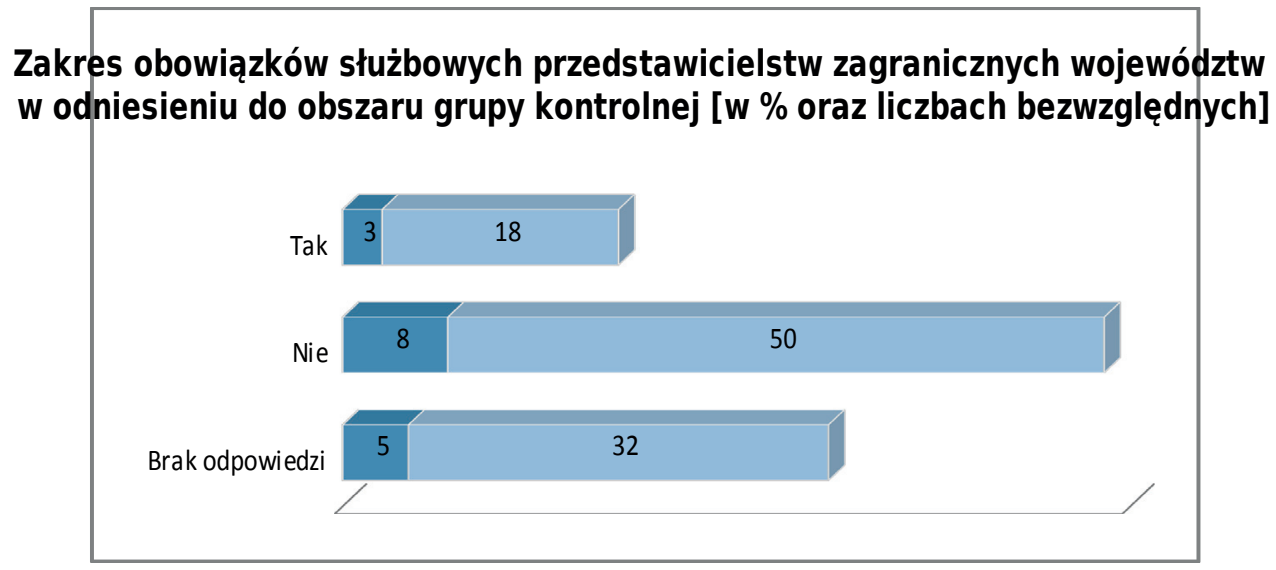

Źródto: Opracowanie własne ( $N=16)$

Nieco ponad 30\% województw wykazało udział w projektach międzynarodowych w obszarze ochrony zdrowia (wykres 9).

Wykres 9. Projekty międzynarodowe realizowane przez województwo w obszarze ochrony zdrowia

Udział polskich województw w realizacji projektów międzynarodowych $z$ obszaru grupy kontrolnej [w \% oraz liczbach bezwzględnych]

Tak

51

Nie

74

Brak odpowiedzi

4

25

Źródto: Opracowanie własne $(N=16)$ 
W zasadzie nie pojawiły się spory we współpracy międzynarodowej w zakresie ochrony zdrowia (wykres 10). Taki wynik badania wydaje się wskazywać nie tyle pełną harmonii kooperację, ile jej wstępny, ubogi w praktykę etap.

Wykres 10. Spory międzynarodowe z udziałem województwa w zakresie ochrony zdrowia

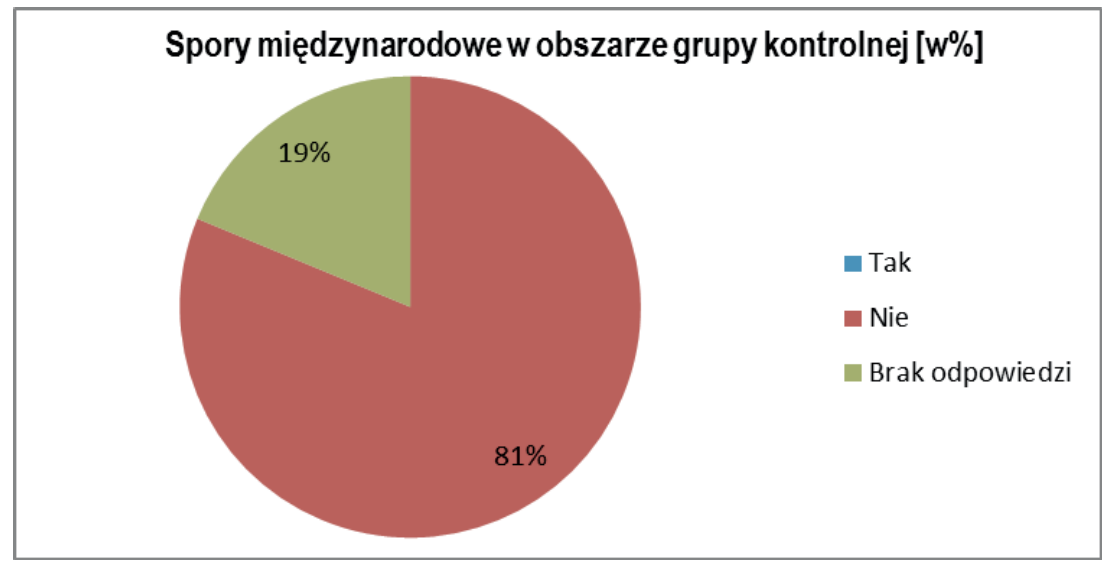

Źródło: Opracowanie własne $(N=16)$

Potwierdzona w badaniach praktyka informowania o województwie w zakresie ochrony zdrowia zmierza w kierunku pełnej dostępności, choć zauważalny jest deficyt rozumienia znaczenia polityki informacyjnej dla zawiązywania i efektywnej realizacji współpracy międzynarodowej województw w zakresie ochrony zdrowia.

Wykres 11. Sposób udostępniania informacji o województwie w zakresie ochrony zdrowia



Źródto: Opracowanie własne $(N=16)$ 
Międzynarodowa współpraca polskich województw w zakresie ochrony zdrowia jest niewątpliwie realizowana. Przynosi też efekty, które nie są póki co znaczące, ale wydają się składać na progresję. To zaś skłania z jednej strony do postulowania ofensywy samorządów wojewódzkich w tym obszarze, a z drugiej do szerszego zainteresowania nauki zarysowaną tu problematyką. Autorki w każdym razie deklarują podtrzymanie zainteresowania w tym względzie i kolejne opracowania tematyczne. 


\section{INTERNATIONAL COOPERATION OF POLISH REGIONS IN THE FIELD OF HEALTH CARE}

Health care is certainly one of the most important public functions, at all levels of the activity - from the international community and the global or regional organizations serving it, through States (which are key subjects in the area), to corporations and individuals. Diversification in public sector management has contributed to entrusting a number of important public tasks, including health care, to regions. Polish voivodships are involved in health care execution managing hospitals and other institutions, implementing health prevention and financing investment and training projects. Increasingly, the issue of health care is included in various forms of their international activities. Obviously - it is performed on varying levels. Both the overall statistics, as well as the review of individual cases lead to the conclusion that there is a progression concerning the issue.

Keywords:

Health care, international cooperation of regions, health in international relations, health care and voivodships 